\title{
Multiculturalism as Indonesian National Identity in Political Satirical Comic Strip on Instagram
}

\author{
Agustinus Dias Suparto \\ Graduate Program \\ Faculty of Letters \\ Petra Christian University \\ agustinusdiassuparto@gmail.com
}

\begin{abstract}
The emergence of social media especially the popularity of Instagram has been used to facilitate people to share their thoughts in public discussion. Comic strip as a work of art which commonly aims as entertainment is also used to promote the value of the author in certain societal issues. Thus, comic strip such as KOSTUM or Komik Strip Untuk Umum (Comic Strip for Public) is using satirical jokes to share the idea of multiculturalism that has been challenged by people who use religious identity, ethnicity and political factions as the thing to differentiate others. Therefore, this paper will try to reveal how this comic strip promotes Indonesian national identity and how the author sees himself as the agent of multiculturalism. Keywords: multiculturalism, religions, ethnicities, identity, political factions
\end{abstract}

\section{INTRODUCTION}

In the era of the rapid development of technology, people around the world are connected by internet through various media. It results on how people now are able to see the world within seconds. They can seek information easily and quickly through internet. Even, they can know what is still happening in other side of the world. Not only that, the emergence of social media fabricates people worldwide to exist in the virtual world in the internet. Their existence in the internet creates a term for its user which is netizen. Internet also facilitates public discussion among netizen about issues in society and they can share their personal feelings and daily activities. Finally, their participation in the social media also becomes the site of showing identity and affiliation toward a particular group of people which will be discussed in this paper.

Many experts have realized that identity of an individual or certain group involves various dimensions of identity, such as gender, age, social status, occupation, ethnicity, nationality or culture (Meijl, 2010, p.68). National identity, according to Meijl (2010) is the result of the development of ethnicity in which it emphasizes the cultural and political construction of nationalism. Gellner (1983) gives his perspective towards nationalism that it evolves naturally as the consequences of the changing nation from agricultural to industrial which demands more homogeneity than existed in the past. However, Anderson (1983) has different point of view of nationalism in which he argued that nationality is the subjective imagination of the nation as a community where it is possible to decline other elements of identity such as religion and it makes people more aware of human diversity with the rise of exploration and the development of capitalism. He added that his view on nationalism is focusing on the subjectivist dimension of nationalism as cultural and political construction (Anderson in Meijl, 2010, p. 70).

In Indonesian context, national identity has been promoted in Sumpah Pemuda or Youth Pledge before the independence of Indonesia as a nation which has one land, one nationality and one language to unify people in Indonesia which have huge number of ethnicity and cultures. Later, the implementation of Pancasila or Five Principles as the national ideology has been successful in guiding the national identity. The slogan Bhineka Tunggal Ika which derives from old Javanese language meaning "Unity in Diversity" also has been successful in promoting multiculturalism because of the fact that Indonesia has more than 600 ethnic groups and cultures (Paauw, 2009). Paauw found out that Bahasa Indonesia plays important part in overcoming the difference in ethnicity and cultures. However, not only diverse in ethnicity and cultures, Indonesia is also diverse in other social elements such as religions as there are six acknowledged religions in Indonesia. Thus, language is not enough to unify diversity in Indonesia and multiculturalism which aims to introduce people to a range of different belief, values, customs and cultural practices can be the 
great way to express respect for and indeed celebration of difference in which Indonesia is very diverse (Ang, 2010). The fact that Indonesia has many kinds group of people, Indonesian national identity through multiculturalism can be the way to create harmony and tolerance within the people. Thus, promoting Indonesia as NKRI or Negara Kesatuan Republik Indonesia which is multiculturalism can be the way of showing Indonesian national identity.

Indonesia which has several religion groups often finds disharmony between groups of people as people sometimes see their religious identity above multiculturalism. Werbner (2010) gave a definition of religious identity as particular way of approaching 'difference' (p. 233). Thus it often creates powerful boundaries, relatedness and otherness on one hand and encompassment and inclusiveness, on the other to challenge, contest and preserve the distinction and unities between groups of people (Werbner, 2010, p.233). Therefore, Werbner added that religious identity can be the way to invoke explanation or legitimization of conflicts between and within religious groups. It emerges whenever groups are torn apart by schismatic or sectarian divisions, or engage among themselves in arguments of identity, often passionate and sometimes violent, even where doctrinal differences appear to be minimal (Werbner, 2010, p.233). As the major source of the satirical humor in KOSTUM is about how intolerance which violates Indonesian multiculturalism comes from several groups of people who are seen as hard line in conveying their religious identity.

Related to personal identity, Jones (1998) also added that identity derives from individual's perception of how other defines that person in a role context, that is whether he feels that others see them as being a part of a group. Thus, people that participate in social media try to also show their identity by doing a particular role in which the identity that is being represented can be fulfilled. Thus, that kind of identification is called "self-presentation" by Goffman in which people tend to behave in certain way to fulfill what he want to be seen by others (in Jones, 1998, p. 49). SelfPresentation is defined by Golfman in Jones (1998) as the attempt of individuals to present a certain image in order to pursue a certain goal. This also is supported by Leary in Jones (1998) that self-presentation can also be defined as the attempt of individuals to control or influence the impressions that others form of them which is aimed to maintain and enhance a social and personal identity. Therefore, the role-identity requires two components, specifically, the role itself and the identity to be associated with that role. It focuses on the ways in which individuals perceive and categorize themselves, based on their social and personal identities. This is later concluded by Jones that self-presentation can also be defined as 'impressions management' (Jones, 1998, p.49). Thus, by using a certain character in the comic, the author of the comic strip wants to show his identity through the role to convey his Indonesian identity.

Finally Hall (1996) gave his argument on how identity works in individual as "the point of suture between, on the one hand, the discourses and practices which attempt to "interpellate", to speak to us or hail us into place as the social subjects of particular discourses, and, on the other hand, the processes which produce subjectivities, which construct us as subject which can be "spoken" (p.6). Thus, he added that identity can be regarded as a never-ending process which always incomplete, unfinished and open-ended.

Instagram, as one of the popular social media in the world which enables its users to posts pictures, has become a tool to show identity. Instagram has been used for creating new identity for its users by using profile pictures, captions and pictures that are posted and shared to other people. As Weeks (2000) has claimed that identity is about belonging and what differentiates oneself to others, people try to built their identity in the social media, especially Instagram by using symbols, images and languages that represent their belonging to particular group of people. Jacobsen (2003) suggested that individuals will base their actions on how they like to see themselves and how they like to be seen by others. For instance, a person represents himself or herself as a member of a particular group by using a group's logo or image and posting his or her support toward his or her group. By doing the role of the identity that is represented, that person wants to build a certain image about himself or herself that he or she belongs to that particular group of people.

Here, KOSTUM which stands for Komik Strip untuk Umum or Comic strip for public tries to join the public discussion through satirical comic about particular occurrences in Indonesia especially political controversy between two factions starting from the Jakarta governor election. Later, it conveys the author's identity through the picture and the conversations that in showed in the comic strip which talk about particular group of people in Indonesia. Comic strips such as 
KOSTUM are comic which are popular in social media such as Instagram which talk about social issue. Ilicescu (2016) also found out that the content which is in the comic strips that is in social media is different with the mainstream comics which are usually in printed form as it talks about real issues in society. The comics in the internet are not focused on the entertainment aspects only because there are more people engaged in the reading the comics. Ilicescu (2016) added that the creators of the webcomics use persuasive narratives which often led to the actual implementation of their subversive messages and thus substantially it contributed to promote social change (p.22).

Artists are more than ever deeply influenced by the cultural, social and political contemporary context in which they live and they become activists when supporting causes, many of the authors choosing to refer directly to the social events of the moment (Ilicescu, 2016, p.22). Thus, the contexts which are brought to the online media are always related to the contexts in which the artists live and the society of the comics that are read. The topics and themes strongly influenced by the ideology of the creators as well as the perspectives of the society on how they see a certain issue. Thus, comic strips are created based on the perspectives of the creators and the readers about the real issue in society in which KOSTUM tries to lift up the societal issues that happen in Indonesia.

The use of sarcasm toward particular groups in the comic strip shows that the author wants to promote identity as a good Indonesian citizen. Thus, by criticizing particular groups that contributes instability and intolerance in Indonesia, KOSTUM wants to promote Indonesian national identity which promotes multiculturalism and tolerance through the roles of the characters in the comic strips because of political and religious identities which violates multiculturalism in Indonesia. The data will be taken from an Instagram account which is called @kostumkomik or Kostum which stands for Komik Strip Untuk Umum (Comic Strips for Public). Some comic strips from that account are taken to be discussed in the perspective of identity that the author wants to promote in the societal issues in Indonesia, especially on the case of Jakarta Governor Election, Ahok's case and Habib Rizieq's case. Therefore, discursive method is used to reveal what kind of identity and perspective about Indonesian multiculturalism that the author has and how it influences the reader through the representations in the comic strips. Finally, this paper will discuss on how KOSTUM in Instagram become the site of showing national identity using satirical jokes which are aimed to particular groups which do not represent good Indonesian citizens.

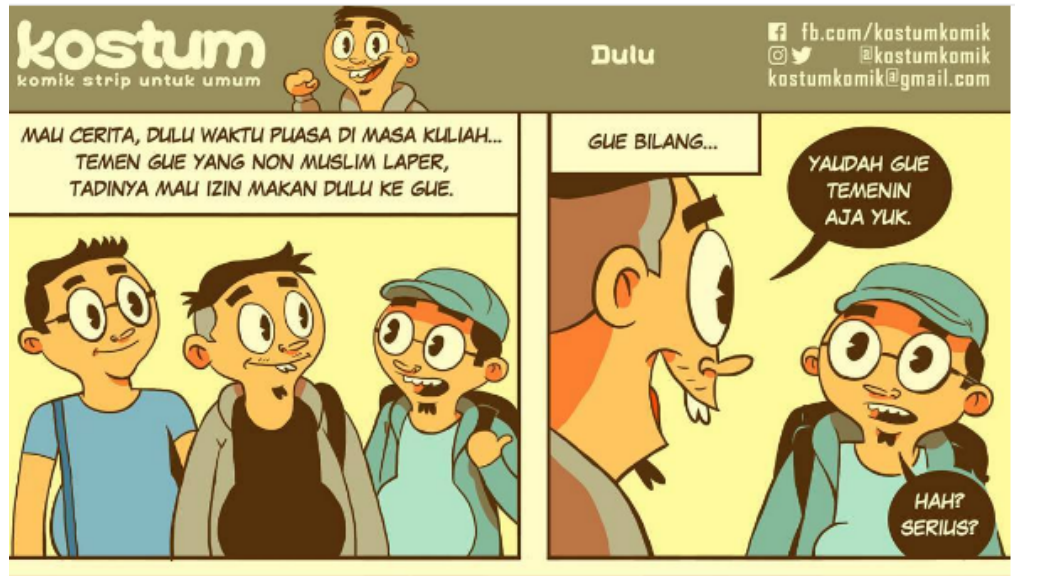

AKHIRNYA KITA DI TEMPAT MAKAN, DI DEPAN GUE, MEREKA MAKAN DAN MINUM, SEMENTARA GLE MASIH TETEP BISA PUASA, DAN KITA TETEP BISA NGOBROL SANTAI.

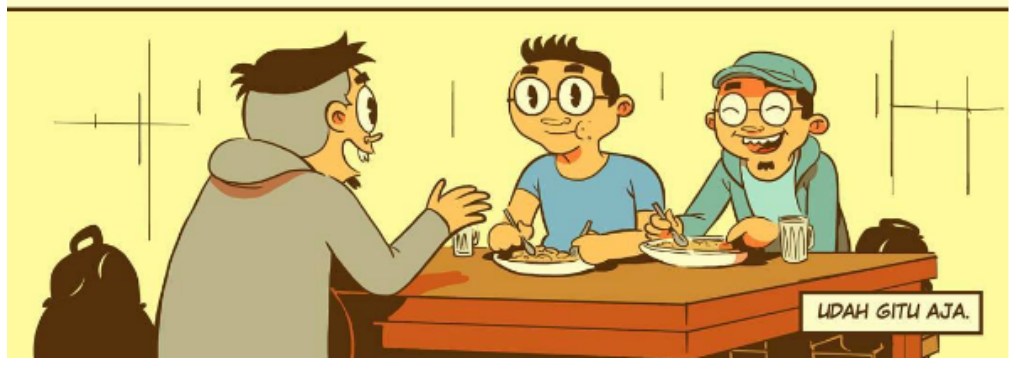

FINDINGS DISCUSSION

\begin{tabular}{lll}
\multicolumn{1}{c}{ As } & Indonesia is a \\
country & which & values
\end{tabular} multiculturalism that a particular social condition of racial and ethnic or cultural diversity, it becomes important to promote tolerance between groups of people who have different religions, ethnics and political factions (Ang, 2010). Thus, KOSTUM as a satirical Indonesian comic strip tries to raise the issues which involve intolerance between people in Indonesia recently like in the picture below.

Title: In the Past

Narration 1: I wanna tell a story, In the past, when I was fasting in my college life...

My non-Muslim friends were hungry; they were going to ask my permission to eat. 


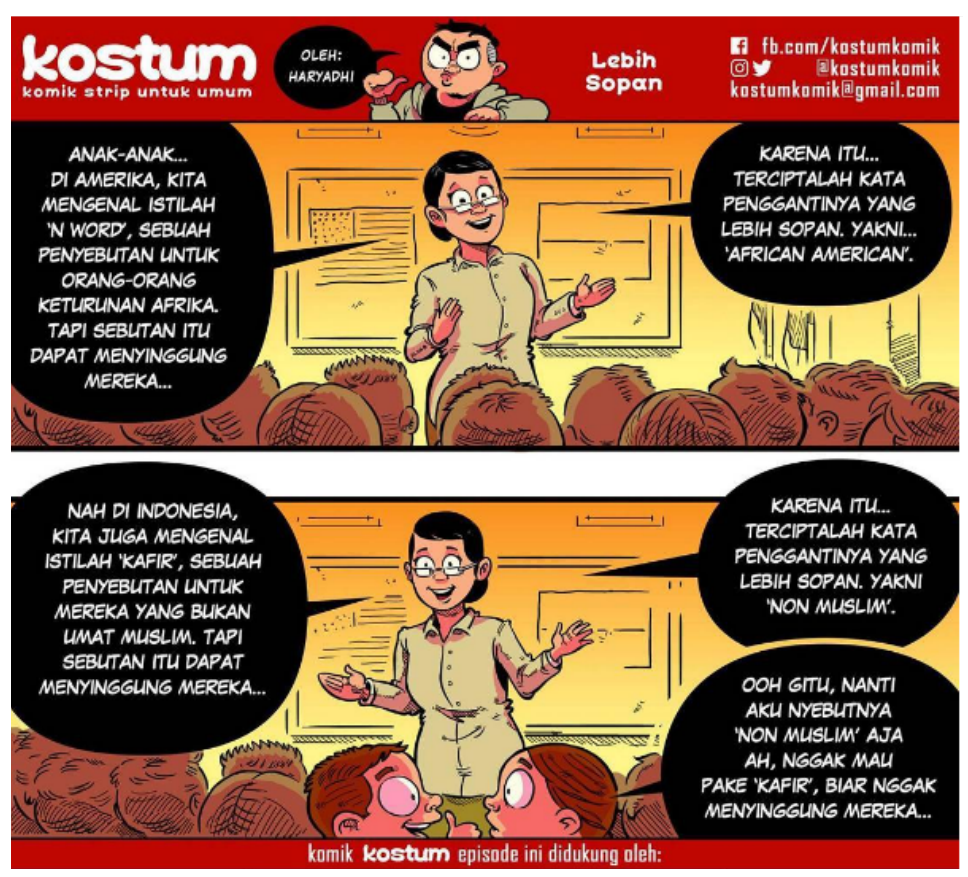

Narration 2: I said...

Author: It's okay, I will accompany

you

Friend: Huh, (are you) serious?

Narration 3: In the end, we ended up in the restaurant, they had their food and drink, whereas I still could do fasting and we still could have conversation conveniently. That's all.

From the story in this comic strip, we can see that in the past, people were more tolerant than now as the result of the weakening of multiculturalism when religious identities or religions create more boundaries between people. The author tells about the story when his non-Muslim friends were going to eat when he was fasting as an obligatory in Islamic Ramadhan month. He implies that it was normal to accompany friend eating while fasting as the symbol of tolerance whereas now many Muslim people who are fasting complaint some restaurants to close in order to respect them. Thus, by comparing the situation in the past and present about religious tolerance, the author wants to imply that Indonesian condition was much better as people had more tolerance than now. It also means that Indonesia needs to strengthen its multiculturalism when people can value unity in diversity as Indonesia has many different religious groups.

Moreover, the author's story about himself that is portrayed in the comic implies that the author wants to show that he is one of the group that is tolerant who does not set boundaries to his friends because of the religious differences. The comic, thus, is a way to show people how tolerance works in Indonesian society by giving the example of what he did in the past as the representation of good Indonesian citizen who has good sense of multiculturalism. As the political tension which was rising during the Jakarta governor election, religious identity is also used to differentiating others. The term kafir is used to label the people who are not Muslim which has negative meaning which is people who do not believe in Allah. Thus, this stereotype is used to attack Ahok as a Christian governor candidate and other people who are not Muslim which implies that people should vote based on the same religious identity.

As the political tension between people gets higher, the author also uses the political factions that are based on religious identity results on stereotyping others like in the conversation between teacher and her students in this comic strip below.

Title: More polite

Teacher: Dear students, In America, we know the term " $N$-word" to describe African descendants. But it can offend them. So, there is the term "African American" which is more polite

Teacher: In Indonesia, we also know the term "kafir", a word to describe people who are not Muslim. But it can also offend them. So, there is the term which is more polite. It's "Non-Muslim" Student: Ah I see, I will use the term "Non-Muslim" instead of "Kafir" because I don't want to offend them.

Actually, the conversation between students and teacher is the sarcasm for those who use the term kafir instead of Non-Muslim which has negative meaning and can offend people who are not Muslim. The use of children as the students symbolizes that the attitude of childish people do not care about other people's feeling by offending them using the term kafir because it can also mean that they do not believe in God, although the term kafir means people who do not believe in Allah. However, the term Allah as God is monopolized by those who think that the terms other than 
Allah such as Tuhan, Bapa, etc do not mean God. Therefore, the author wants to clarify that the using of Non-Muslim which is more polite can also maintain the harmony of people who are diverse in religions. Therefore, it also implies the multiculturalism to respect other religions.

The using of issue of Chinese descendants that have been living since the independence of Indonesia makes the political tension higher. The using of the term cina also creates negative sense toward Chinese descendants that live in Indonesia. That term also creates an issue which is Chinese economic colonization toward those who are considered as pribumi or Indonesian indigenous people which was popular during Dutch colonization as the way to decriminalize people at that time. The term cina is also used to stereotype people as communist as Indonesia has fear of communist movement. We can see how Indonesian people also create boundary using ethnicity, especially Chinese to differentiate between cina and pribumi.

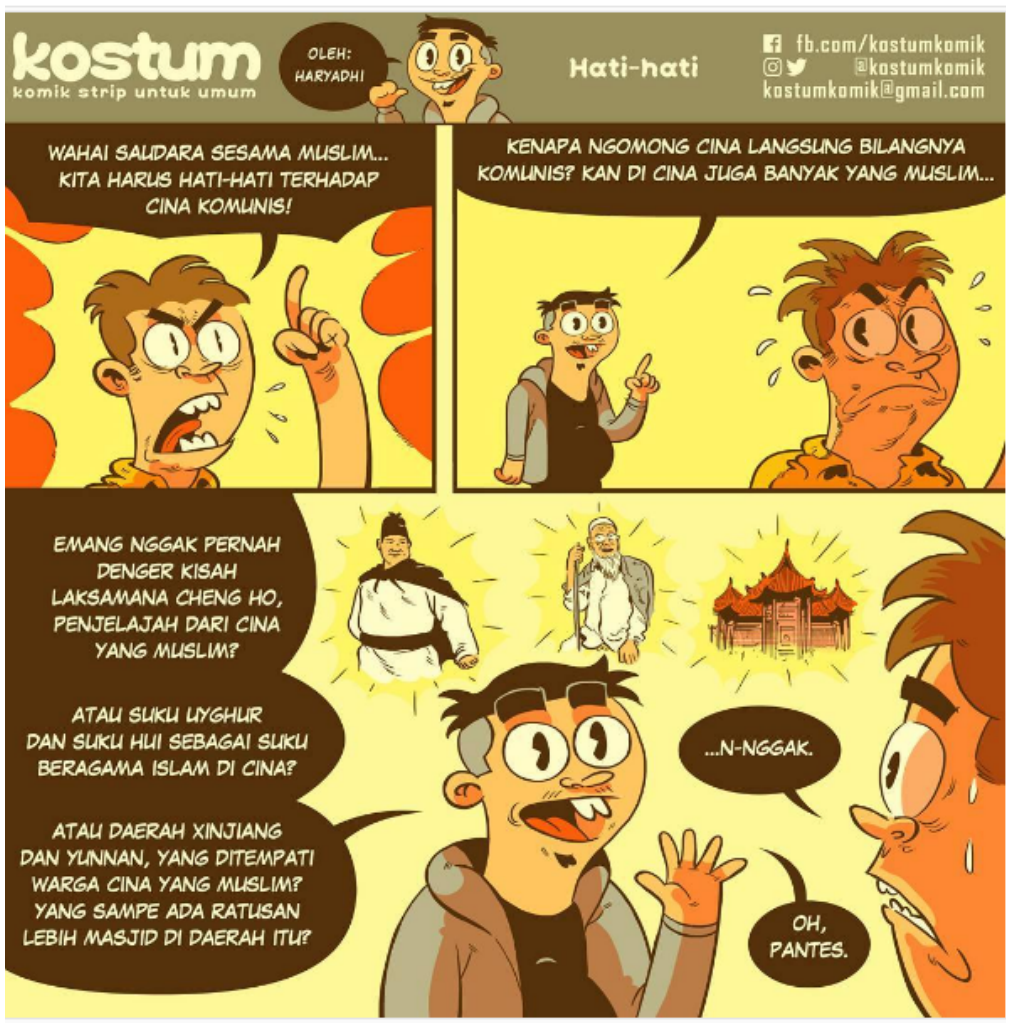

Author: Why do you imply that Chinese is always communist? In China, there are also many Muslims

Author: Have you heard the story of Admiral Cheng Ho, the sailor from China who was Muslim?

Or the Uyghur and Hui people who are also Muslim in China? Or Xianjiang and Yunnan where Chinese people who are Muslim live? (Do you also know) there are more than hundreds of Mosques in that area?

The man: Nope

Author: Ah, That's why (you do not know it).

The conversation in the comic between the author and a person who labels Chinese as Communist is also criticized in the comic strip as the person who likes to judge without having the sufficient knowledge. Thus, it also implies that the author wants to identify those people as intolerant because there are many Chinese descendants who live in Indonesia and love Indonesia. Thus, the author also wants to underline that being good Indonesian is not stereotyping other ethnicity and accepting Chinese descendants as part of Indonesia because Indonesia is based on multiculturalism. The idea of communism that has been banned in Indonesia because of the incident in the past and now is used as the weapon to attach Chinese descendants in Indonesia is also criticized. Thus, by telling that person that there are also Muslims in China also creates the sense that Muslim does not affiliate with a certain ethnic group such as those in Arabic countries. Moreover, the story of how Chinese people spread the religion into Indonesia also shows that China cannot be associated with communism as there are also Chinese people who contributed in the spreading the religion to Indonesia in the past.

Moreover, the author wants to see how the fundamentalist people label Republic of China as the threat because of the ideology of communism that is popular in China and see Saudi Arabia as the example of the country that Indonesia should adopt because of the Islamic law that is purely 
implemented in that country. Thus, there are groups of people who dream of the emergence of Khilafah in which Muslim laws are implemented and idolize King Salman as their ideal leader and Saudi Arabia as the ideal nation. Therefore, the author wants to remind people who want Khilafah in Indonesia that as a good Indonesian citizen, they should be proud of being Indonesian and support the president for the sake of the nation. It also implies that to be good Indonesian citizen, they also should have their pride of their identity, especially the ideology of Pancasila or The Five Principles as the best ideology for Indonesia. It can also be interpreted that those who see Saudi Arabia and Republic of China that way as the close minded people who just see things from one perspective which is religious identity. Moreover, the author also wants to show to those groups of people who see Khilafah as the best ideology or the implementation of Muslim laws in Indonesia that Pancasila was founded by the founding fathers because of the diversity that Indonesia.

Later, people are still thinking about the difference of religions and ethnicity in Indonesia as people who are not educated as they cannot accept the diversity in Indonesia as Indonesia was founded by the idea of multiculturalism. Thus, the comic strip below shows how the author

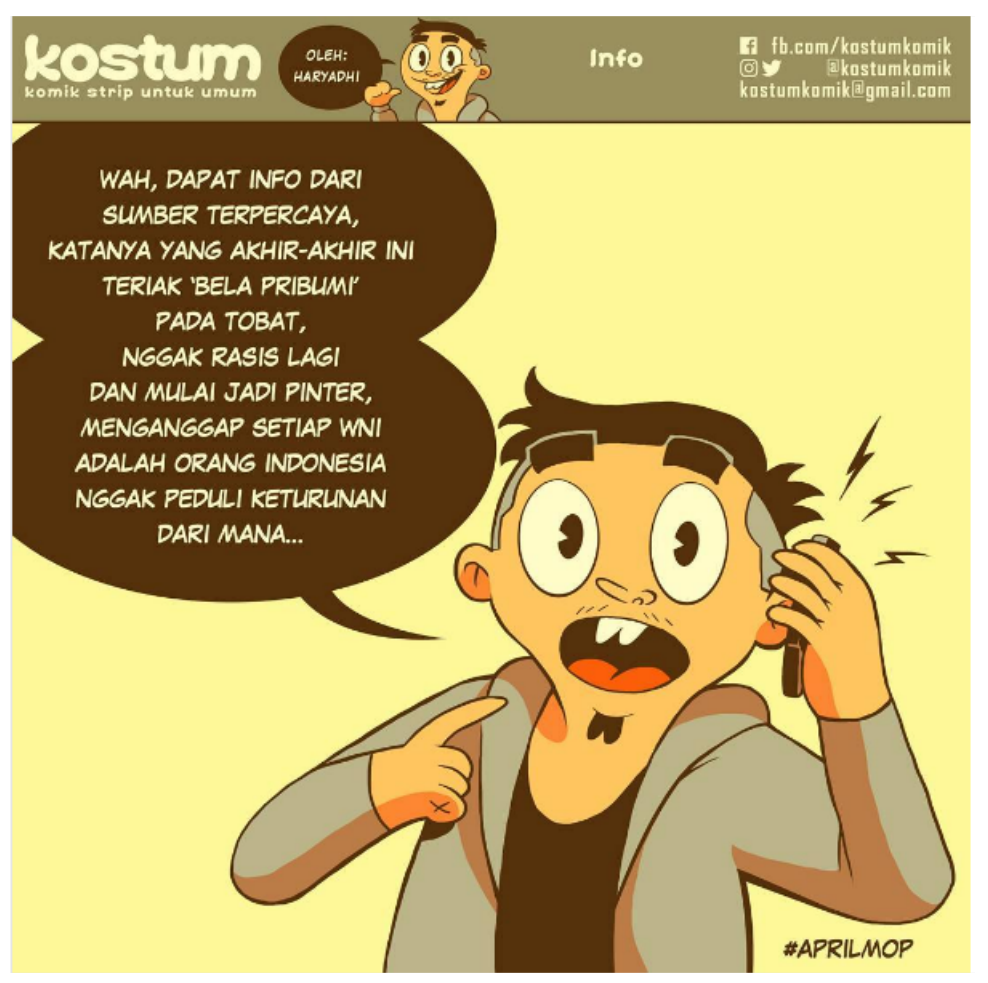
identifies those people by using the sarcasm of April Mop which has the opposite meaning of what he says below.

Title: Info

Author: Ah, (I) got some information from the trusted source that recently, those who shout "Bela Pribumi (Save Indigenous People)" have repent, not being racist anymore and are getting more intelligent to admit every Indonesian citizen is Indonesian, (and) do not care about which descendant the people are from... \#AprilMop

From the comic, the author uses the April Mop as the sarcasm toward racist people in Indonesia that still differentiate indigenous and non-indigenous people, such as Chinese who live in Indonesia. The issue of indigenous people was also used in the election of Jakarta when Basuki Tjahaja Purnama or Ahok was competing in the Governor election. However, many people still believe in that issue which make people hate each other based on ethnicity. Thus, the author also boldly identifies that people who still differentiate people based on ethnicity in Indonesia are not intelligent as Indonesian identity is based on multiculturalism. Therefore, the sarcasm used in the comic is used to make people realize that only stupid people will threat people based on ethnicity in Indonesia. Here, the author also represents himself in the comic as the character who conveys the message as he also wants to represent his identity as a good Indonesian who is not racist.

Moreover, the author also wants to emphasize that the act of racism can affect towards children which will bring bad impact in the future in order to maintain multiculturalism in Indonesia. The hate towards difference of ethnicity that the children have is actually inspired from the adults that the author wants to criticize below. 
Friend: This is bad, there was elementary student who was tortured just because he looks like Ahok

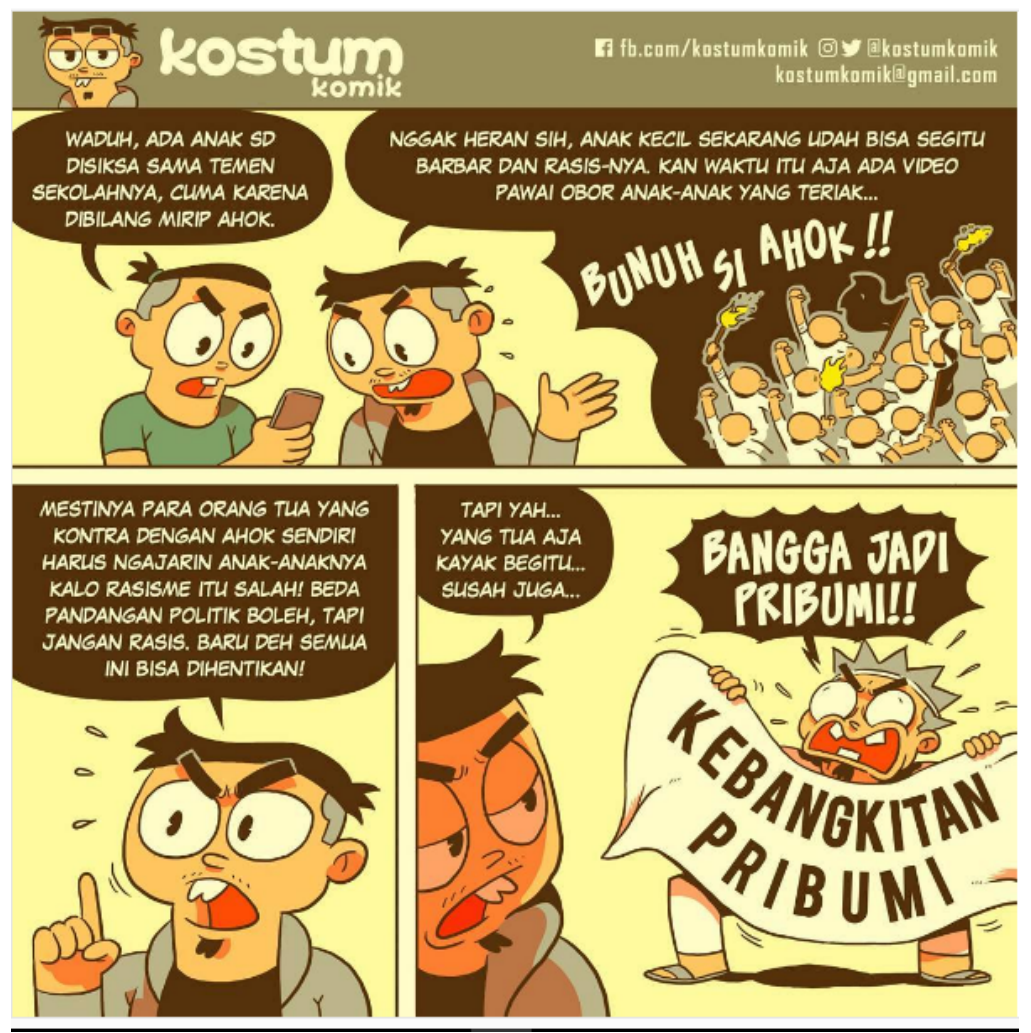
Author: It's not surprising; kids nowadays can be so barbaric and racist. (We know that) there was a video showing kids parading using torches while shouting "Kill Ahok!"

Author: Surely, the parents who are opposing Ahok should have taught their children that racism can't be tolerated. Having different political perspective is okay, but don't use racism. Then, all of this mess can be stopped.

Author: But, the adults are like that. (So, that's) difficult (to stop racism).

A White Lion Member: Proud to be Indigenous!

Sign: "The resurgence of Indigenous People"

From the conversation of the author and his friend, he is criticizing the effect of political difference which uses the issue of racism. He emphasized the importance of parent guidance in order to maintain the multiculturalism which is the idea of Pancasila or The Five Principles that has been believed by Indonesian people to be the national identity and ideology. However, the adults who should have been the example of maintaining the multiculturalism seem to be failed as there are still many demonstrations, hoaxes, provocative speeches which involve racism, especially the sentiment towards Chinese descendant which is the result of the political factions during the Jakarta governor election. Moreover, as the election is over in which Anies Baswedan emerged as the winner, the controversy on racism goes on. Anies's speech of the emergence of pribumi or indigenous people as the new Jakarta governor has been inspiring more people to hate Chinese descendant in order to maintain the political faction which may be used in the Presidential election or other elections to gain the support from people who believe in the indigenous people resurgence.

The use of a white lion army who like stereotyping others based on religion and ethnicity also symbolize a group of people who are criticized by the author. The use of sign of "Indigenous people resurgence" that is inspired by the real phenomenon in Jakarta is also used to show how those people who believe in the resurgence as the act of violating multiculturalism that has been maintained until now. Thus, the authors also criticize those people because their act of racism will inspire Indonesian young generations to do the same thing in Indonesia like the examples that are mentioned in the story such as hating other people who have different ethnicity. Thus, the author seems pessimistic that the racism in Indonesia can be stopped because there are still many people who still hate each other based on difference in ethnicity, especially towards Chinese in Indonesia.

As the differences of religions and ethnicities, the other identities such as political identity are used to differentiating others, the comic shows that there is a way to maintain unity in diversity which is football. However, the euphoria of football cannot last for a long time as it only makes people forget of their differences for a while. 


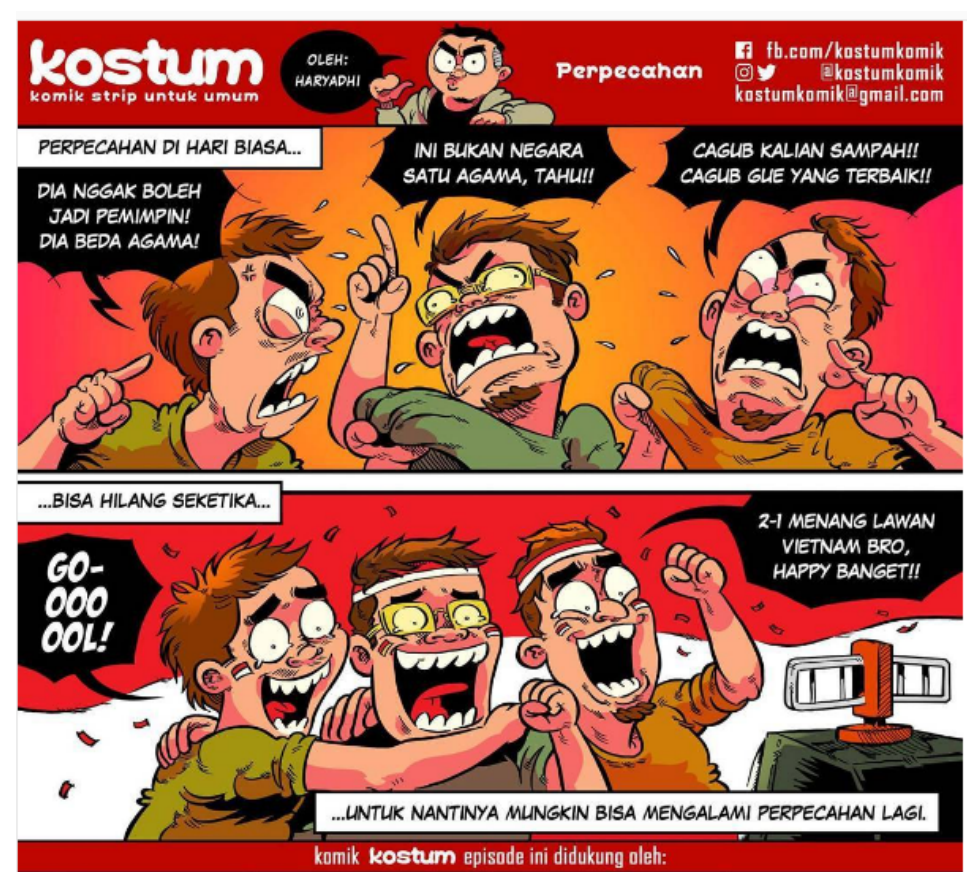

Title: Disunity

Narration: Disunity in usual day

A: He should not be the leader! He

has different religion!

$B$ : This is not one religion nation, you know!

C: Your candidates suck!! My candidate is the best!!

Narration: Can be suddenly disappear....

C: 2-1 win versus Vietnam, bro, (I'm) so happy!!

Naration: For the next, can suffer disunity again...

In this case, it shows that political tension in Jakarta governor election has created political factions that are also based on the difference of religious identity. However, the author reminds the reader that regardless their differences, such as religious, ethnicity and political identity in Jakarta governor election; they are still Indonesian which should be in unity like what happen when Indonesian national team is competing against other country. This actually shows that people in Indonesia are still recognizing their national identity and they are still proud of being Indonesian.

However, this also can be the sarcasm for the Indonesian people who still think that differences in religion, ethnicity and political faction as the source of stereotyping others. This can also show how people easily forgets the multiculturalism that has been maintained as the ideology in Pancasila as the recognition as Indonesian or their national identity does not last long. This can also show that people in Indonesia put their national identity below their religion identity and ethnicity. Therefore, the author wants to promote multiculturalism that has been the ideology in uniting the diversity in Indonesia as the attempt to remind Indonesian people of their national identity.

\section{CONCLUSION}

As Indonesian national identity is based on multiculturalism where people can accept differences in religion, ethnicity and political faction, the author wants to remind the readers that all Indonesian citizens are Indonesian who should be treated without any discrimination. Thus, by using satirical jokes toward particular groups of people who still cannot be tolerance towards others, the author identifies these people as close-minded people which do not have the sense of Indonesian national identity as they cannot value multiculturalism. Therefore, he also implies that being Indonesian, people should be more aware in diversity and accept the differences of religious identity, ethnicity and political factions in order to show national identity (Anderson, 1983). By having more awareness in multiculturalism, this comic strip implies the importance of putting national identity above other identities such as religious identity and ethnicity.

Moreover, by using certain characters including the author himself in the comic strips, he wants to show his identity as a person who is tolerance and can value differences in religions, ethnicity and political factions. Thus, he identifies himself as the one who has good nationalism in which he can show the example of how Indonesian people should be like in his character. Therefore, the comic strip can be also the mean of the 'impressions management' of the author of KOSTUM (Jones, 1998, p.49). The role of his character in the story and the way he tells the readers about the social issue using his satirical jokes also can be the way of fulfilling his role as an Indonesian who is proud of Indonesian national identity which is multiculturalism and Pancasila as the national ideology. 


\section{REFERENCES}

Anderson, B. (2006). Imagined Communities: Reflections on the Origin and Spread of Nationalism. London: Verso

Ang, I, 2001. On Not Speaking Chinese. London: Routledge

Illiescu, A. 2016. The Comic Strip - A Weapon for Social Criticism. Research about, through and for Art. Vol 1(1). (pp.17-28)

Jones, I. (1998). Football Fandom: Football Fan Identity and Identification in Luton Football Club. Bedfordshire: University of Bedfordshire Press

Paauw, S. (2009). One land, one nation, one language: An analysis of Indonesia's national language policy. In H. Lehnert-LeHouillier and A.B. Fine (Eds.), University of Rochester Working Papers in the Language Sciences, 5(1), 2-16.

Weeks, J. (1990). The Value of Difference. In J. Rutherford (Ed.), Identity: Community, Culture, Difference (pp. 88-100). London: Lawrence \& Wishart.

Wetherell, M and Mohanty, C, 2010. The Sage Book of Identity. London: Sage Publications Ltd. 